\title{
難透水性地盤におけるバイオレメディエーションのための浄化促進剤投入方式 に関するウォータージェットを用いた現場実証試験
}

\author{
上沢 進 ${ }^{1}$, 張 銘 ${ }^{2}$, Robert C. Borden ${ }^{3}$, 駒井 武 ${ }^{4}$ \\ 1 ケミカルグラウト株式会社 本社 \\ 2 産業技術総合研究所 地質調査総合センター 地圈資源環境研究部門 \\ 3 EOS Remediation, LLC \\ 4 東北大学 環境科学研究科
}

\begin{abstract}
概 要
バイオレメディエーションでは，水素徐放剤の投入による埩化促進が可能であるが，難透水層の場合，注 入方式では薬液の浸透性, また, 攪挥方式では地盤の泥濘化の問題がある。筆者らは, 対応策として, 難透 水層における水素分子の拡散効果に着目し，また理論的基礎検討により明らかになった平面的拡散方式の 優位性を活かし，一定の離隔で水素徐放剂をウォータージェットで切削した薄膜状スリットに投入する浄 化手法を考案した。薄膜離隔は上下方向で $0.3 \mathrm{~m}$ とて 2 現場で実証実験を行った。その結果, 低濃度污染 サイトでは 8.5 箇月でほぼ完全に浄化され, 高濃度污染サイトでは最大濃度 $75 \mathrm{mg} / \mathrm{L}$ であったテトラクロロ エチレンが 2 年間でほぼ環境基準值 $(0.01 \mathrm{mg} / \mathrm{L})$ レベルまで分解された。これら現場試験の結果より，ウ オータージェットによる埩化促進剤の投入と平面的拡散を併用した技術の有効性が実証された。
\end{abstract}

キーワード : バイオレメディエーション, クロロエチレン類, 難透水層, 水素徐放剤, ウォータージェット

\section{1. はじめに}

環境への配慮が様々な局面においてなされてきており， 土壌や地下水污染についても日本では 2003 年に法制化さ れた。土壌污染対策法に指定された特定有害物質は揮発性 有機化合物（VOCs）, 重金属等, 農薬等に分類されるが, これまでの統計調査ではVOCs と重金属類による污染サ イト数はそれぞれ約 3 割と 6 割以上を占める。土壌污染の 浄化措置には, 掘削除去, 地下水揚水, ガス吸引, 封じ込 め, 不溶化或いはバイオレメディエーションなど様々な方 法が存在する。

なお，実際の土壌污染サイトでは，污染物質を除去する という確実性から掘削除去が最も多く用いられている 1)。

しかし，掘削除去は運搬・処理を伴うことからコストが 高く土地所有者に過剩負担をかけ, 結果として, 売却や再 利用ができずに放置されてしまう土地の発生を招いてい る。また, 除去した土壌による二次污染の恐れ, 重機作業 や運搬に伴う二酸化炭素の多量排出など, 課題が多い。

さらに, 2010 年の土壌污染対策法の改正に伴い, 浄化措 置の掘削除去への偏重を減らし, 污染土壤搬出による二次 污染の拡大を防ぐため, 污染サイトで行う浄化措置, つま り原位置浄化による対策が求められている。

我が国では, VOCsによる土䁃污染としてテトラクロロ エチレン（PCE）, トリクロロエチレン（TCE）などのクロ
ロエチレン類による污染が多く, これら物質は水より比重 が大きく粘性も低いため浸透性が高く, 地層の深い部分や 帯水層下部の難透水層にまで広がっている場合が多い。ま た，この難透水層に浸透・滞留した污染物質の透水層への 再溶出についても問題視され，シミュレーションによる検 討もなされている 2)3)。そして, シルト層などの難透水層 での污染土壤対策を掘削除去により行った場合, 比較的深 い位置まで多量の土壤を掘削し場外搬出することとなる ことから高コストとなるケースが多い。

一方, VOCs は有機化合物であるため, 分解・無害化に よる浄化が可能であり, 化学的または微生物学的分解によ る原位置浄化技術を利用できる。VOCsにより污染された 難透水層を対象とした原位置浄化技術の中で代表的なも のとしては, 污染土壌を酸化剤や還元剂等の薬剤と強制的 に混合・攪拌する機械攪拌工法がある。しかし，この方式 では杭打設機等の大型重機が必要となり, 狭险な場所では 施工できず，また，地表面まで攪拌せざるを得ない。この 問題に対応する技術として, 任意の深度のみを小型の装置 で施工できるウォータージェットを用いた薬液混合方式 が考案され実用に供されている ${ }^{4) 5}$ 。 但し, ウォータージ エットを用いた薬液混合方式でも, 機械擋拌工法と同様に 擋拌による地盤の強度低下を招く問題のほか, コストも比 較的高い。

別の VOCs 污染土壌の原位置浄化技術として, 微生物の 
分解能を利用した浄化手法（バイオレメディエーション） があり，コスト面や環境負荷の面で優れていることから， 最近ではよく用いられるようになってきている。一般的な バイオレメディエーション手法は, 污染位置に井戸を設け, 分解性微生物を活性化させる薬剤を地中に自然浸透もし くは低圧で注入する方式であり，透水層においてよく用い られている。近年では, クロロエチレン類の有用分解微生 物が難透水性土壌においてもその生息が確認されている ものの ${ }^{6778)}$, 上記注入方式であると薬剤が地盤中に浸透し にくく, 薬剤と土壌とが均等に接触できない問題がある。 そこで，著者らは水素徐放剤に着目し，難透水層におけ る水素分子の拡散について, 室内実験により拡散係数とそ の影響因子に関しての研究開発を進めてきた。

この室内実験で，標準砂とカオリン混合土，カオリン粘 土及び粘土堆積層試料など複数種類の試料を用いて実施 した水素拡散試験の結果から, 粘土質試料においても拡散 係数が $10^{-10} \mathrm{~m}^{2} / \mathrm{s}$ オーダーにあることが明らかになった ${ }^{910) 。 ~}$ また, 実際の現場で利用可能な浄化促進剤投入方式として, 難透水層直上の帯水層或いはウォータージェットで掘削 したスリット面を利用した平面的拡散, ボーリング孔を利 用した中空円筒形拡散及びボーリング孔底を利用した中 空球形拡散に対する理論的基礎検討を行い, 平面的拡散を 利用した浄化促進剂の投入方式が最も効率的あることが 明らかになった ${ }^{11)}$

本稿では，ウォータージェットを用いた原位置浄化技術 と従来の井戸注入及び機械攪拌技術との比較・検討を行う とともにウォータージェットによるスリット面の作成と 浄化促進剂の平面的拡散を融合した技術の有効性を, 現場 実験にて検証した。

\section{2. ウォータージェットを用いた原位置浄化技術と 従来技術の比較}

\section{1 ウォータージェットを用いた原位置浄化技術}

ウオータージェットを用いた原位置浄化技術として，覺 拌噴射方式とスリット噴射方式がある。両者の概念図を図 1 に示す。

攪拌噴射方式では, 酸化剤あるいは鉄粉などの還元剤を ジェットで噴射し，地盤中の污染土壤と混合させる。浄化 のメカニズムとして主に化学的分解となり, 污染物質の濃 度に殆ど依存せず，また浄化期間が短い等の利点がある。 しかし，薬液は液体で噴射し，全対策区域で攪拌・混合す るため，切削域が泥濘化する等の問題がある。一方，スリ ット噴射方式では, 対策地層中で一定の間隔で薄いスリッ 卜を切削し，その中に水素徐放剤などの浄化促進剤を投入 する。水素徐放剤から放出される水素がスリット面の両側 へ拡散し, 電子供与体として嫌気性微生物によるクロロエ チレン類の脱塩素分解に寄与し，浄化が促進される。この 脱塩素分解のメカニズムを図 2 に示す。なお, 図中で DCE はジクロロエチレン，VCはクロロエチレンを示す。

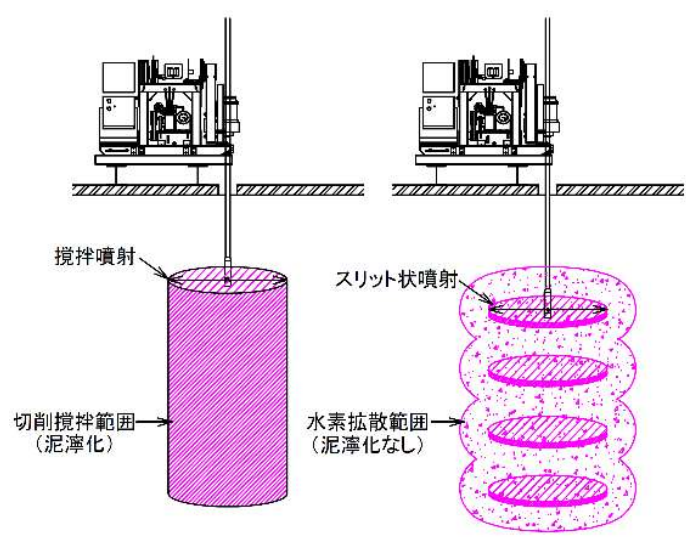

$\begin{array}{ll}\text { (a) 擋拌噴射方式 } & \text { (b) スリット噴射方式 }\end{array}$

図 1 ウォータージェットを用いた原位置浄化技術の概念

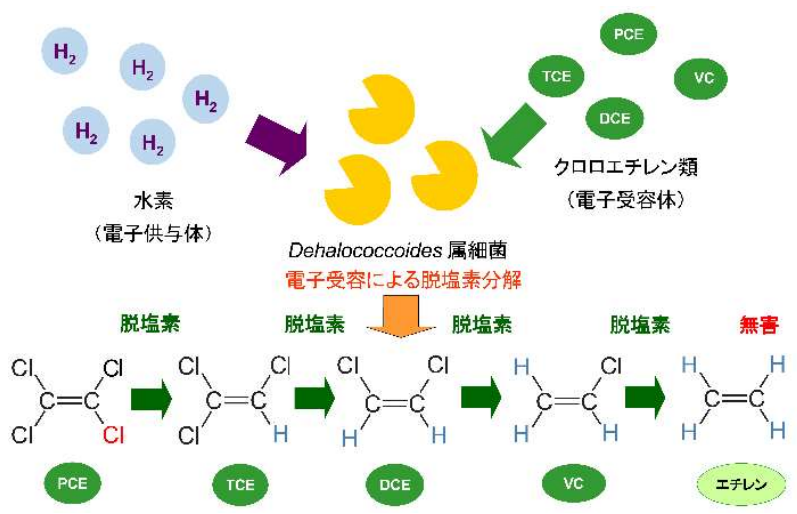

図 2 水素を用いた微生物による脱塩素反応の概念

表 1 ウォータージェットを用いた原位置浄化技術の比較

\begin{tabular}{|c|c|c|}
\hline & $\begin{array}{l}\text { 擋汼噴射方式 } \\
\text { (従来方式) }\end{array}$ & 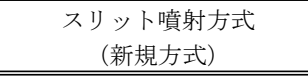 \\
\hline $\begin{array}{l}\text { 浄 } \\
\text { 化 } \\
\text { 方 } \\
\text { 法 }\end{array}$ & $\begin{array}{l}\text { 鉄粉, 酸化剤等を混練した } \\
\text { 液体を, 超高圧で回転しな } \\
\text { がら噴射し, 細かいピッチ } \\
\text { で引上げることにより, } \\
\text { 土壌と強制混練して接触 } \\
\text { させて化学反応等で浄化 } \\
\text { させる }\end{array}$ & $\begin{array}{l}\text { 微生物分解を促進するため } \\
\text { の浄化促進剂 (例えば, 水素 } \\
\text { 徐放剂) を一定の間隔で円 } \\
\text { 盤状に噴射し, 水素分子の } \\
\text { 円盤状スリット両側への拡 } \\
\text { 散により, 全対策領域の浄 } \\
\text { 化を促進させる }\end{array}$ \\
\hline $\begin{array}{l}\text { 浄化 } \\
\text { 期間 }\end{array}$ & $\begin{array}{c}\text { 短期 } \\
\text { (数週間〜数か月以内) }\end{array}$ & $\begin{array}{c}\text { 長期 } \\
\text { (半年以上) }\end{array}$ \\
\hline $\begin{array}{l}\text { 適用 } \\
\text { 範囲 }\end{array}$ & 高濃度污染でも対応可能 & 適用濃度に限界あり \\
\hline $\begin{array}{l}\text { 地盤の } \\
\text { 泥浮化 } \\
\end{array}$ & 粘性土地盤では発生する & $\begin{array}{c}\text { 粘性土地盤でも発生しにく } \\
\text { い } \\
\end{array}$ \\
\hline $\begin{array}{l}\text { 排泥 } \\
\text { 発生量 }\end{array}$ & $\begin{array}{l}\text { 対象土壤全量に対し噴射 } \\
\text { する為, トータル噴射量が } \\
\text { 多く, 排泥も多い }\end{array}$ & $\begin{array}{l}\text { 薄膜状に噴射注入するた } \\
\text { め, トータル噴射量が少な } \\
\text { く排泥も少ない (噴射攪拌 } \\
\text { 式の } 2 \text { 割程度) }\end{array}$ \\
\hline コスト & 高 & 低 \\
\hline
\end{tabular}

浄化のメカニズムとしては, 主に微生物学的分解であり, 化学的分解より時間がかかる。また, 有用微生物生息の有 無や污染物質の濃度等に制約されることもある。

しかし，この手法は低コスト・低環境負荷の浄化技術と して期待できる面があり，また，従来の噴射撹挥方式では 
地盤切削間隔が $2 \sim 3 \mathrm{~cm}$ であるのに対して，スリット噴射 方式ではこの間隔を 10 倍以上確保することから泥濘化問 題が大幅に改善される。表 1 にウォータージェットを用 いた原位置浄化技術の比較をまとめる。

薄膜状のゾーンを造成する方法としてはフラクチャリ ング方式があり，報告された事例もある。フラクチャリン グ方式とは, 砂と浄化薬剤や微生物を混練したものを難透 水層中に圧入して地盤を割裂させつつ薄膜状に注入する ことにより，これに接する面から浄化を進める考え方であ

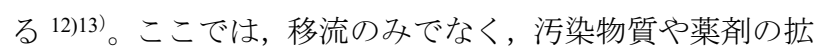
散に着目した報告もなされているが, 水素の地盤中におけ る拡散速度を考慮した技術ではなく，また，注入域を制御 できないこともあり，浄化効果は明確にされていない6)。

\section{2 スリット噴射式と従来技術との比較}

従来技術として, 井戸を用いた薬液注入と機械攪拌があ る。井戸注入の薬剤として酸化剂, 還元剂或いは浄化促進 剂のいずれも可能であるが, 難透水層への適用は困難であ る。機械攪拌は酸化剤或いは鉄粉などの還元剤の混合に利 用できるが，対策深度に制限があり，また地表面まで全部 攪挥する必要がある。スリット噴射方式と従来技術との比 較を表 2 にまとめる。

\section{3. スリット噴射式を用いた現場実証試験}

現場実証試験は, 微生物による污染物質の分解性と浄化 促進剤添加条件を決定するためのトリータビリティー試 験, ウォータージェットによる污染浄化領域への浄化促進 剂の投入および土壤サンプリングの採取による浄化効果 の確認によって実施した。

ここでは，ウォータージェットを用いた原位置浄化技術 の工程と二つの実污染サイトへ適用した事例を紹介する。

\section{1 ウォータージェットを用いた原位置浄化技術}

ウォータージェットを用いた原位置浄化技術の工程を 図 3 に示す。ボーリング孔による削孔を所定の噴射深度 まで実施した後, まずロッドを回転させながら高圧で清水 を噴射し, 薄膜状のスリットを切削する。その後, 噴射剂 を浄化促進剤に切り替え, 再度高圧噴射を行い, スリット に浄化促進剤を投入する。噴射完了後, 次のスリット深度 までロッドを引き上げ, 再び清水を噴射し, 浄化促進剂を 投入するためのスリットを切削する。この作業を繰り返し， 浄化対象区間に必要枚数の薄膜状の浄化促進剤注入域を 造成する。なお，噴射による埩化促進剤の投入は，スリッ ト毎に繰り返して行うのではなく, 必要枚数のスリットを 切削した後，まとめて順番に投入することも可能である。 後者は前者より作業効率を向上させることも可能である。 また, 切削スリットの間隔については, 「難透水性地盤に おけるバイオレメディエーションのための浄化促進剂投 入方式に関する研究 ${ }^{11)} 」 の$ 理論的基礎検討の結果を踏ま え, 浄化に一定濃度以上の水素濃度が必要であること及び
表 2 スリット噴射式と従来技術との比較

\begin{tabular}{|c|c|c|c|}
\hline 方式 & $\begin{array}{l}\text { 井戸注入 } \\
\text { (従来技術) }\end{array}$ & $\begin{array}{l}\text { 機械攪挥 } \\
\text { (従来技術) }\end{array}$ & $\begin{array}{l}\text { ウォーター } \\
\text { ジェット } \\
\text { (スリット噴射 } \\
\text { 方式) } \\
\end{array}$ \\
\hline 薬剤 & $\begin{array}{l}\text { 水素除放剤・ } \\
\text { 酸化剤など }\end{array}$ & $\begin{array}{c}\text { 酸化剂・鉄粉 } \\
\text { など }\end{array}$ & 水素除放剂 \\
\hline $\begin{array}{c}\text { 難透水層への } \\
\text { 適用性 } \\
\end{array}$ & 困難 & 適用可 & 適用可 \\
\hline $\begin{array}{l}\text { 污染源対策 } \\
\text { (高濃度污染) } \\
\end{array}$ & $\begin{array}{c}\text { 化学的分解 } \\
\text { では可能 }\end{array}$ & 可能 & 適用限界あり \\
\hline $\begin{array}{c}\text { 任意深度への } \\
\text { 対策 } \\
\end{array}$ & 可能 & 困難 & 容易 \\
\hline 施工機械 & $\begin{array}{c}\text { 小型 } \\
\text { (ボーリング } \\
\text { マシン) }\end{array}$ & $\begin{array}{c}\text { 大型 } \\
(\text { ベース } \\
\text { マシン) }\end{array}$ & $\begin{array}{c}\text { 小型 } \\
\text { (ボーリング } \\
\text { マシン) }\end{array}$ \\
\hline 地盤の泥濘化 & 発生しない & 発生する & 殆ど発生しない \\
\hline 対策可能地盤 & 砂質土地盤 & 軟弱地盤 & $\begin{array}{l}\text { 砂質土 : } \mathrm{N} \leqq 200 \\
\text { 粘性土 : } \mathrm{N} \leqq 9\end{array}$ \\
\hline 排泥発生 & 微量 & 多い & 少ない \\
\hline $\begin{array}{c}\text { 単価 } \\
\text { (直接工事費) }\end{array}$ & - & $1 \sim 2$ 万円 $/ \mathrm{m}^{3}$ & $\begin{array}{c}\text { 同左 } \\
\text { (軟弱地盤) }\end{array}$ \\
\hline $\begin{array}{c}\text { 浄化期間 } \\
\text { (粘性土浄化) }\end{array}$ & - & 1 ヶ月以上 & 半年以上 \\
\hline
\end{tabular}

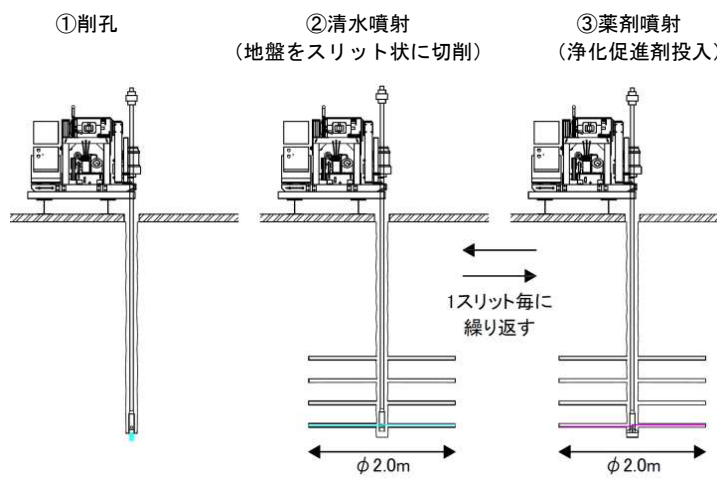

図 3 ウォータージェットによる浄化促進剤投入工程

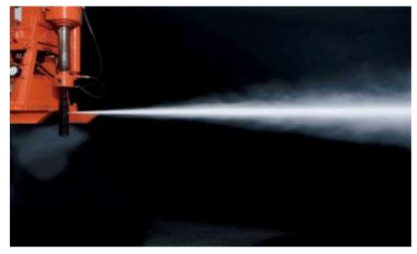

(a) ウォータージェット

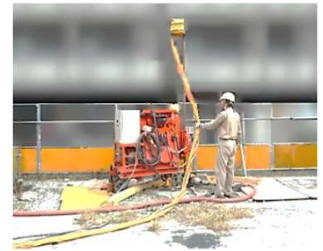

(b) 現場作業状況
図 4 ウォータージェット及び現場作業のイメージ

浄化期間の短縮などの観点から, 後ほど紹介する二つの実 証試験ではいずれも $0.3 \mathrm{~m}$ とした。ウォータージェットの 噴射状況及び現場作業のイメージを図 4 に示す。

\section{2 高濃度污染サイトでの実施事例}

\subsection{1 サイトAの地質及び污染状況}

実験箇所は，都内某所のクリーニング工場跡地で，污 染サイト (本稿ではサイトA で記す) の土質柱状図を図 5 に示す。透水層は GL-0〜-9m であり，それ以深はシルトを 
表 3 サイトAの污染状況（単位 : $\mathrm{mg} / \mathrm{L}$ )

\begin{tabular}{|c|c|c|c|c|}
\hline \multirow{2}{*}{$\begin{array}{l}\text { 深度 } \\
\text { (GL) }\end{array}$} & \multicolumn{3}{|c|}{ 対象物質 } & \multirow{2}{*}{$\begin{array}{l}\text { 土 } \\
\text { 層 }\end{array}$} \\
\hline & $\begin{array}{c}c i s-1,2- \\
\text { DCE }\end{array}$ & TCE & PCE & \\
\hline$-0.5 \mathrm{~m}$ & ND & ND & 0.010 & \multirow{9}{*}{$\begin{array}{l}\text { 透 } \\
\text { 水層 }\end{array}$} \\
\hline$-1.0 \mathrm{~m}$ & ND & ND & 0.001 & \\
\hline$-2.0 \mathrm{~m}$ & ND & ND & 0.014 & \\
\hline$-3.0 \mathrm{~m}$ & 0.019 & 0.006 & 0.044 & \\
\hline$-4.0 \mathrm{~m}$ & ND & ND & 0.001 & \\
\hline$-5.0 \mathrm{~m}$ & $\mathrm{ND}$ & $\mathrm{ND}$ & 0.004 & \\
\hline$-6.0 \mathrm{~m}$ & ND & ND & 0.004 & \\
\hline$-7.0 \mathrm{~m}$ & 0.007 & 0.001 & 0.004 & \\
\hline$-8.0 \mathrm{~m}$ & 1.9 & 0.81 & 6.3 & \\
\hline$-9.0 \mathrm{~m}$ & 5.2 & 2.4 & 75 & \multirow{4}{*}{$\begin{array}{l}\text { 難 } \\
\text { 透 } \\
\text { 水 } \\
\text { 層 }\end{array}$} \\
\hline$-10.0 \mathrm{~m}$ & 3.1 & 0.003 & 0.059 & \\
\hline$-11.0 \mathrm{~m}$ & 0.005 & 0.004 & 0.004 & \\
\hline$-12.0 \mathrm{~m}$ & $\mathrm{ND}$ & ND & 0.002 & \\
\hline $\begin{array}{l}\text { 溶出 } \\
\text { 基準 }\end{array}$ & 0.04 & 0.03 & 0.01 & \\
\hline
\end{tabular}

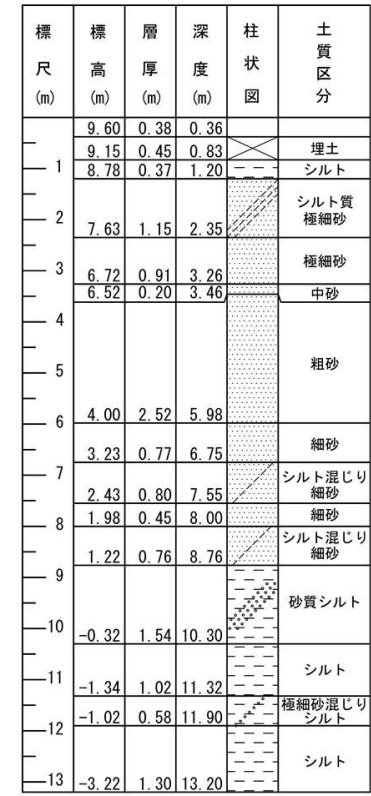

図 5 サイトAの土質柱状図

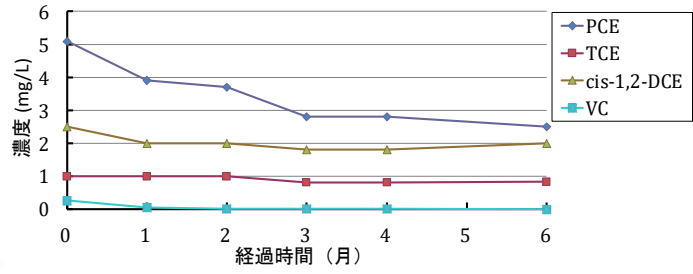

(a) Control

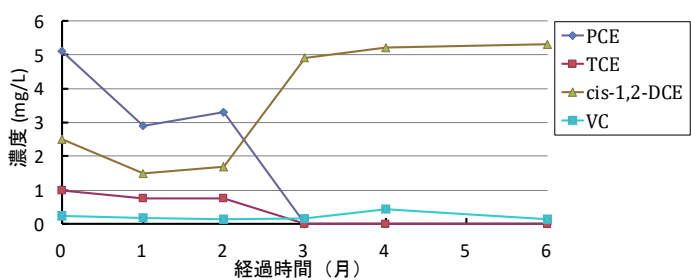

(b) タイプ A

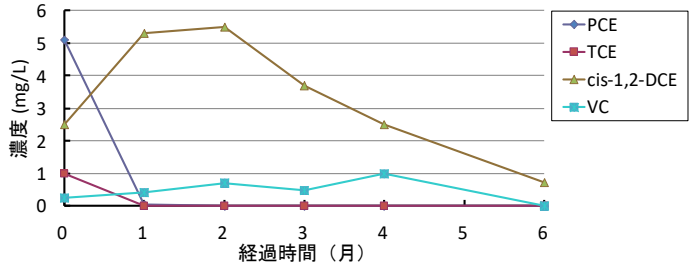

(c) タイプ B

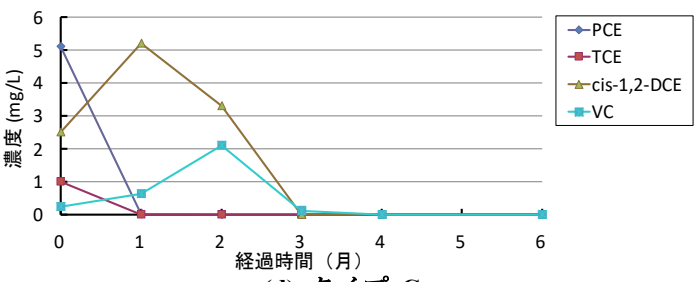

(d) タイプ $\mathrm{C}$

図 6 サイトAのトリータビリティー分解試験結果

あるクロロエチレン(VC)も加えた。

水素徐放剤が無添加のものについては, 分解速度が遅く, 有意な分解性が確認できなかった。水溶性基質のもの（夕 イプA）については，高い分解性は確認できたが，cis-1,2DCE が 6 箇月経過時点では分解が進んでおらず，添加薬 剤が消費されてしまったと考えられる。植物性基質の薬剤 2 種類については cis-1,2-DCE の分解速度に差異は発生し たがどちらも高い分解性が確認された。このことから, 現 場実証実験のステップに進むこととした。

\subsection{3 サイトA での原位置実証試験} (1) 浄化促進剂の投入条件

ウォータージェットによるサイト A での浄化促進剂の 投入条件を表 4 に示す。ここで, 噴射量と圧力については, 汎用性が高く地盤改良でよく用いられる超高圧ポンプの 仕様より設定した。また，スリットの間隔は，水素分子の 拡散速度に関する解析結果 ${ }^{11}$ )を参考に決定した。

ここで, 浄化剂噴射範囲の確認は, 清水噴射を加熱水で 行うことにより, 地中に事前に設置した熱電対の温度変化 を目視で観測した。なお，記録計を併用した噴射範囲の確 認方法に関する説明は，「3.3 低濃度污染サイトでの実施 事例」の項にて記録計データを示して述べる。 
浄化促進剂は水素の徐放持続期間を 3〜5 年間持続でき るタイプ B を使用した。

\section{(2) 浄化効果の確認方法}

浄化効果を確認する為, 土壤試料採取によるモニタリン グを行った。試料採取位置は, 図 7 に示寸とおりであり, 浄化体打設直後に土壌サンプリングを実施した No.1-(1) 孔と No.2-(1)孔の近傍に 20〜30 cm の離隔で実施した。土 㙥採取は, 浄化体打設の 7 力月後, 13 力月後, 25 力月後 に実施した。また，分析項目は PCE と分解生成物である $\mathrm{TCE} ・ c i s-1,2-\mathrm{DCE} ・ \mathrm{VC}$ とし。

No.1 孔を打設した直後および 7 ケ月後のサンプリング は, 図 8 に示寸深度位置で実施し, GL-7.5, -8.4, -9.3,-10.2m の土壤を採取分析し，4 深度における調査を行った。13 カ 月後および 25 カ月後については, GL-7.5, -8.4, -9.3,-10.2m の土壤に加えて, 土壌深度毎の濃度のバラツキを解消する 目的で GL-7.0m〜-11.0m（合計 4.0m）のオールコアサンプ ルを $0.25 \mathrm{~m}$ 毎に分割して試料を各々分析し，ボーリング 1 本当たり合計 20 深度の調査を実施した。

No.2 孔を打設した直後および 7 ケ月後のサンプリング は，図 9 に示寸深度位置で実施し，GL-8.1，-9.0，-9.9，$10.8 \mathrm{~m}$ の土壌を採取分析し，4深度における調査を行った。 13 力月後および 25 力月後については, GL-8.1, -9.0, -9.9, $-10.8 \mathrm{~m}$ の土畩採取に加えて, 土壤深度毎の濃度のバラツキ を解消する目的で GL-7.5m〜-11.5m（合計 $4.0 \mathrm{~m}$ ) のオール コアサンプルを $0.25 \mathrm{~m}$ 毎に分割して試料を各々分析し，ボ ーリング 1 本当たり 20 深度の調査を実施した。

なお，上述した， $25 \mathrm{~cm}$ 毎のサンプルには各々にほぼス

\begin{tabular}{|c|c|c|}
\hline \multirow{2}{*}{$\begin{array}{c}\text { 噴射量 } \\
\text { (圧力 : 40MPa) }\end{array}$} & 清水（地盤切削） & $70 \mathrm{~L} / \mathrm{min}$ \\
\hline & 浄化促進剤（注入） & $70 \mathrm{~L} / \mathrm{min}$ \\
\hline \multicolumn{2}{|c|}{ 対象範囲 } & $\Phi 2.0 \mathrm{~m}$ \\
\hline \multirow{2}{*}{ 対象（H=3.0m） } & No.1 & GL-7.5m -10.5m \\
\hline & No.2 & GL-8.0m -11.0m \\
\hline \multicolumn{2}{|c|}{ 注入ゾーン土量 } & $9.42 \mathrm{~m}^{3} /$ 本 \\
\hline \multicolumn{2}{|c|}{ スリット数 } & 11 スリット \\
\hline \multicolumn{2}{|c|}{ スリット間隔 } & $0.3 \mathrm{~m}$ \\
\hline
\end{tabular}

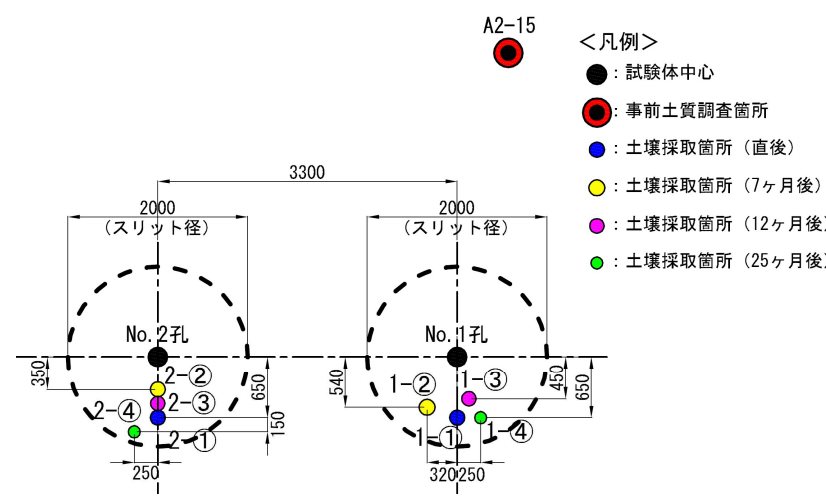

図 7 サイト A における浄化効果確認のためのボーリング孔配置図
リット 1 枚が含まれ，このスリット部は地盤切削水や浄化 剂の置換効果により半分程度に污染濃度が低下すると推 定される。しかし，スリット自体の厚さは $2 \mathrm{~cm}$ 未満の薄膜 状のものであり, スリット閒隔 $30 \mathrm{~cm}$ に対しては 1 割以下 であることから，スリット部を含む濃度分析であっても全 体の污染濃度変化を評価する上では特に大きな問題はな いと判断した。

\section{(3) 浄化効果}

\section{1) No.1 孔の調査結果と考察}

No.1 孔における浄化の進捗をモニタリングした結果を 図 10 に示す。PCE の最大濃度が，打設直後のモニタリン グ結果で $1.5 \mathrm{mg} / \mathrm{L}$ （GL-8.4m）であったのが， 7 カ月後で

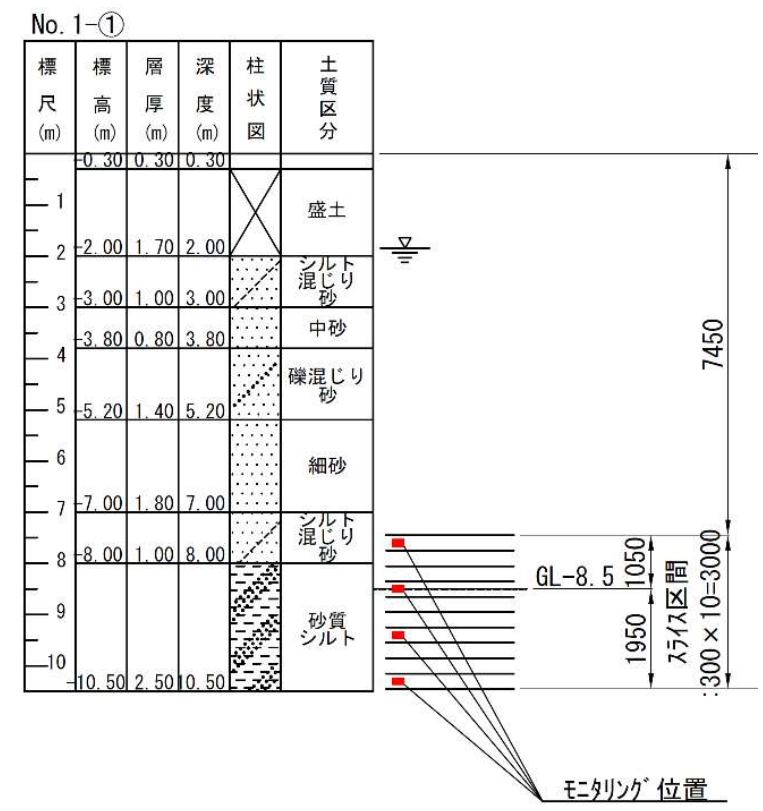

図 8 No.1 孔付近土㙵試料採取深度分布

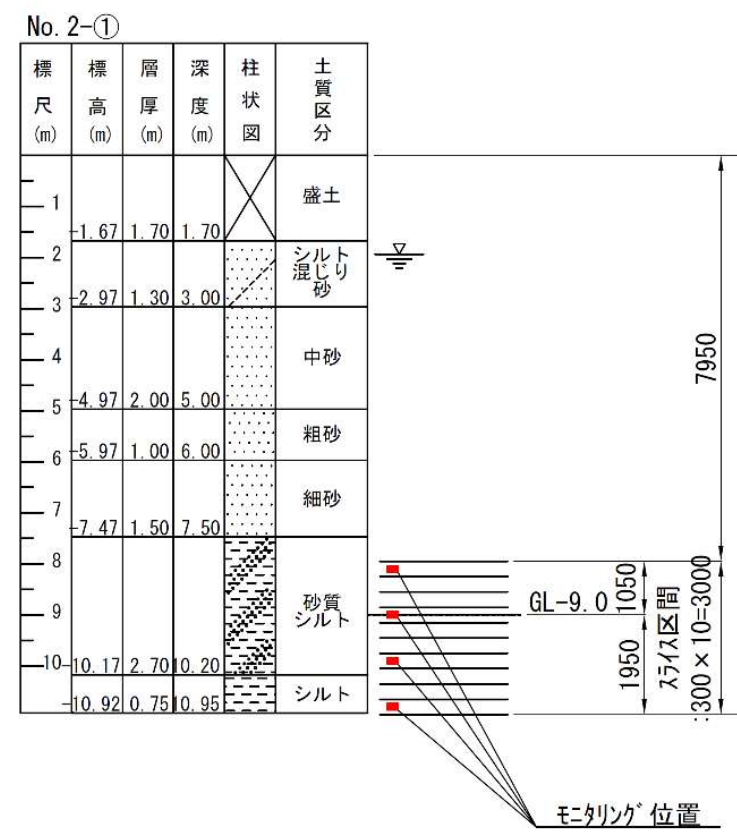

図 9 No.2 孔付近土壤試料採取深度分布 


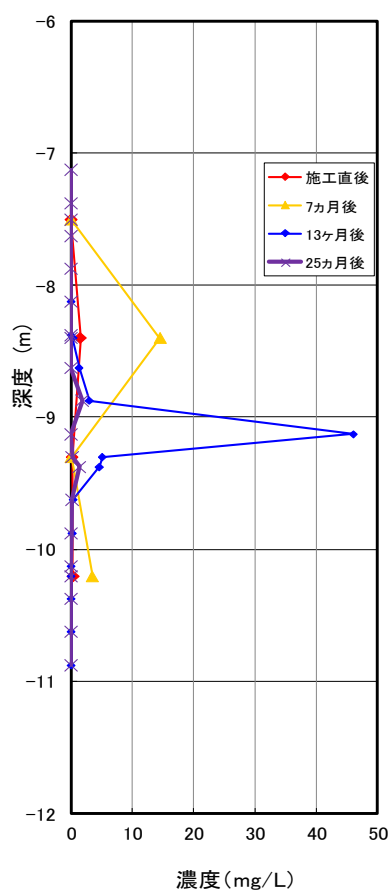

(1) PCE

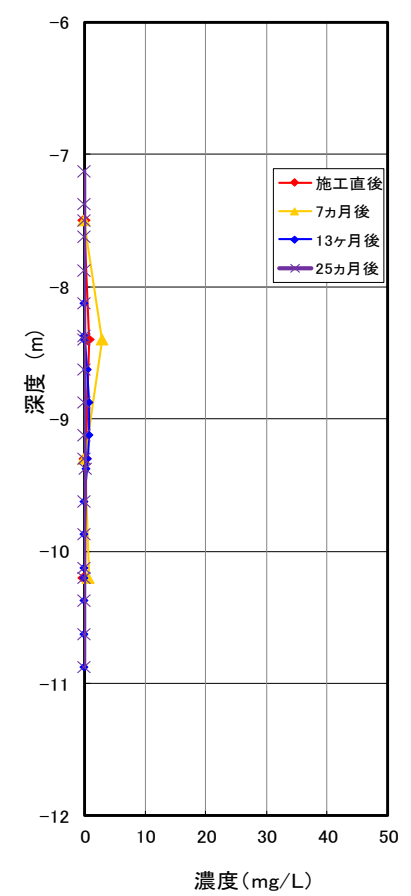

(2) TCE

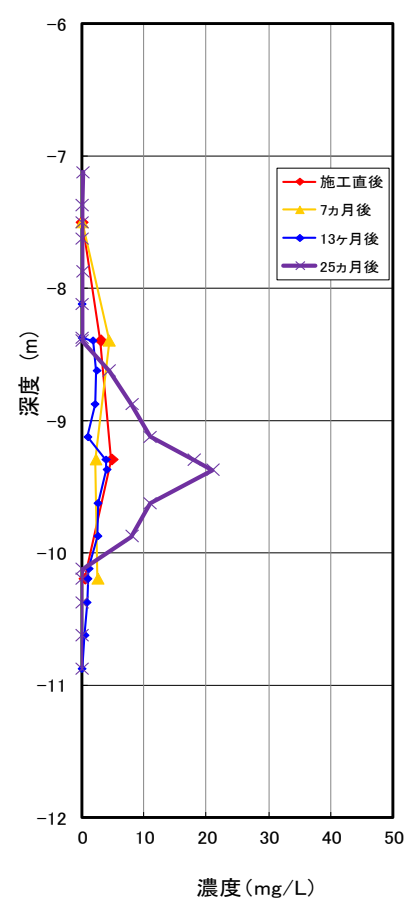

(3) $c i s-1,2-\mathrm{DCE}$

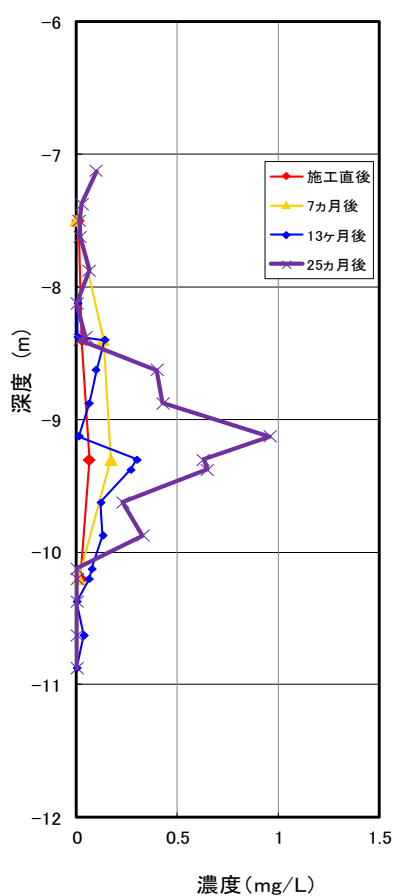

(4) $\mathrm{VC}$

図 10 No.1 孔における浄化の進捗状況

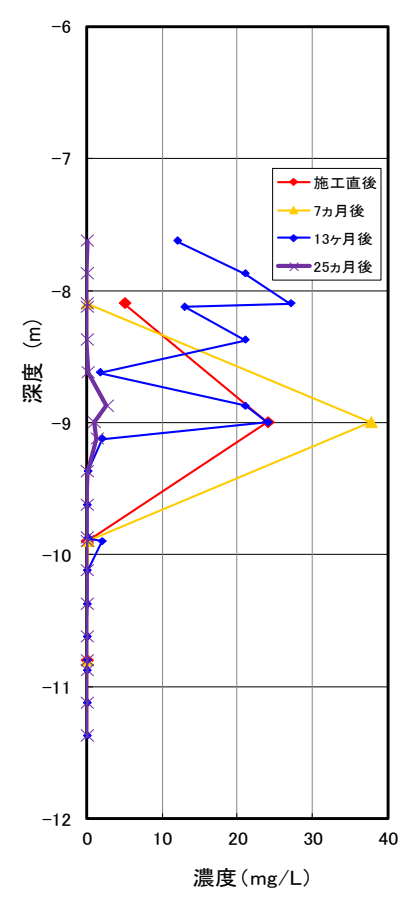

(1) $\mathrm{PCE}$

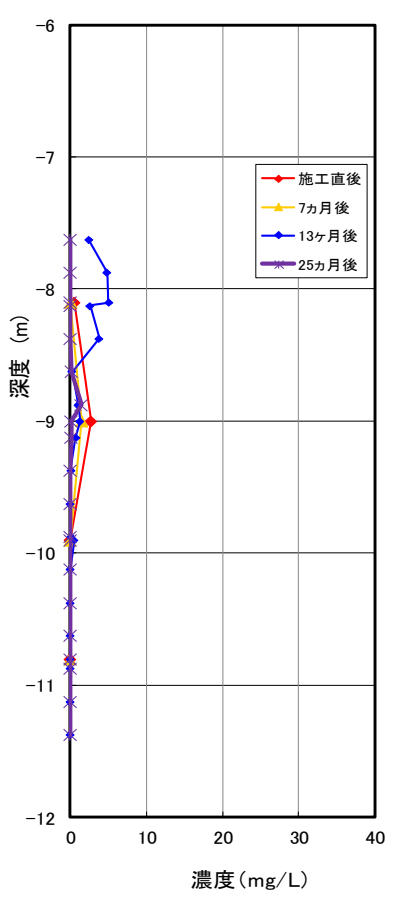

(2) TCE

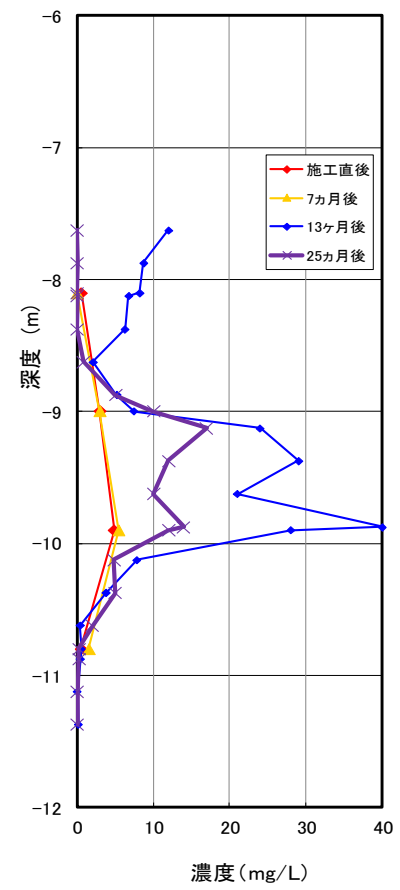

(3) $c i s-1,2-\mathrm{DCE}$

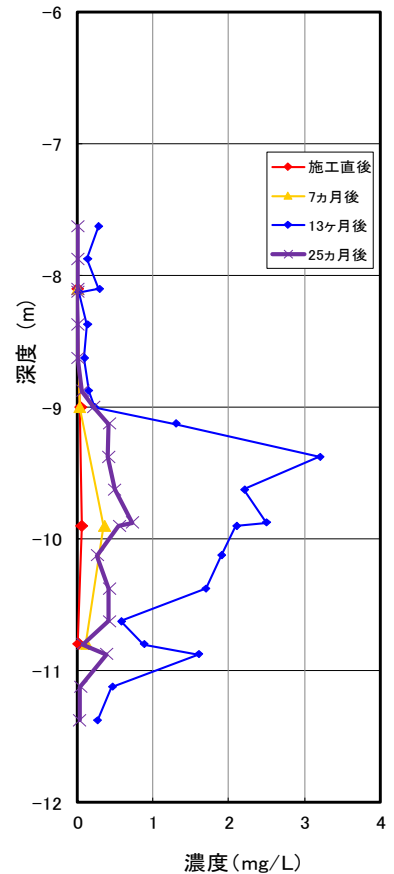

(4) $\mathrm{VC}$

図 11 No.2 孔における浄化の進捗状況

$15 \mathrm{mg} / \mathrm{L}$ （GL-8.4m）に大きく上昇しており，これはサン プルの採取方法による濃度のバラツキであると考えられ る。このため，これ以降のサンプリングは前節で説明した $0.25 \mathrm{~m}$ 毎の混練試料を利用する方法へ変更した。その結果, 13 力月後の調查では, GL-9.1 mにおいて, PCEの最大濃度 が 46mg/L で確認され, ここでの TCE は $0.79 \mathrm{mg} / \mathrm{L}$, cis-1,2-
$\mathrm{DCE}$ は $0.96 \mathrm{mg} / \mathrm{L}$ となっており, 高濃度部については分解 があまり進んでいないと判断された。これに対して, 25 カ 月後においては, PCE が全体で分解が進んでおり, GL-8.9m にて $1.9 \mathrm{mg} / \mathrm{L}$, また, GL-9.4m にて $1.4 \mathrm{mg} / \mathrm{L}$ という 2 ポイ ントのみが，やや高濃度で検出されたが，この 2 深度を除 いて, PCE 濃度は寸べて $0.2 \mathrm{mg} / \mathrm{L}$ 以下に分解されていた。 
分解生成物である cis-1,2-DCE は，上記 2 深度において， $8.0 \sim 21 \mathrm{mg} / \mathrm{L}$ と大きな值を示しており, さらに, cis-1,2-DCE の分解生成物である VC が最大で $0.96 \mathrm{mg} / \mathrm{L}$ で検出されて おり，13 力月後における VC の最大值である $0.30 \mathrm{mg} / \mathrm{L}$ か らさらに増加していた。

高濃度部においても分解が進行していることが確認さ れ，全体としてグラフで示されるように 25 箇月経過で微 生物分解が大きく進んだことが確認された。

\section{2) No.2 孔の調査結果と考察}

No.2 孔における浄化の進捗をモニタリングした結果を 図 11 に示す。 7 カ月後において, cis-1,2-DCE の最大濃度 が GL-9.9mで 4.9mg/L であったのが, 13 カ月後において は, GL-9.1〜-9.9mで 21〜 40 mg/L と高い值を示しており, かつ, $\mathrm{VC}$ も最大で $3.2 \mathrm{mg} / \mathrm{L}$ が検出されていることから分 解が大きく進行していることが伺えた。さらに, 25 力月後 においては, PCE が高く検出されているのは, GL-9m 付近 の 1.0 2.6mg/L のみであり, この深度を除いては, すべて $0.2 \mathrm{mg} / \mathrm{L}$ 以下になっていた。また, 上記の GL-9m 付近の深 度において cis-1,2-DCE は 5.1〜 17mg/L と大きな值を示し ており，25ケ月経過することにより，PCEの高濃度污染部 においても分解が確認された。

なお, cis-1,2-DCE の分解生成物である VC は, 13 力月 経過後の值として GL-9.1m では $1.3 \mathrm{mg} / \mathrm{L}$ ，また， GL-9.4m では VC の最大值となる $3.2 \mathrm{mg} / \mathrm{L}$ を示していたが, 25 ケ月 経過の值は, GL-9.1m では 0.42mg/L, GL-9.4m では $0.41 \mathrm{mg} / \mathrm{L}$ となっており, 大きく低下する方向にあり, グラフで示さ れるように分解生成物も含め, 全体の污染濃度が漸減の方 向にあるものと推定される。

\section{3 低濃度污染サイトでの実施事例}

\subsection{1 サイトB の地質及び污染状況}

実験箇所は, 関西地区某所の稼働中工場敷地内で, VOCs の污染が深度 GL-13m 付近まで存在している。

土質調査結果を図 12 に示す。また, 污染調查結果は表 5 に示すとおりである。なお, 黄色着色部は土壌溶出量基 準值を超過している部位を示す。

今回実験したサイトは, すでに揚水と井戸方式の水素徐 放剂注入により浄化処理が実施されており, 帯水砂層部で は良好に浄化が進んでいるものの, GL-9m 程度以深に堆積 する難透水性のシルト層や互層として存在する透水性の 低いシルト混り細砂層部においては污染が残存していた。

\subsection{2 サイトB 浄化のためのトリータビリティー試験}

サイト A 浄化のためのトリータビリティー試験と同様 に, メジューム瓶 $(500 \mathrm{~mL})$ に現地の難透水層から採取し た土壌を $134 \mathrm{~g}$ 投入し, ここに現地から採取した滅菌地下 水を $266 \mathrm{~g}$ 注水して全体として $400 \mathrm{~g}$ に調整した。ここに, 試薬として TCE を 40mg 添加して含有量として $100 \mathrm{mg} / \mathrm{kg}$
となるサンプルを作製した後, 所定の量の水素徐放剤を添 加した。水素徐放剤の種類としては大豆油を主成分とした もの 1 種類とし, 添加量は, 試料全体重量の $0.2 \%$ をべー スとして 3 種類, 無添加のものと合わせて計 4 ケースにつ いて試験を実施した。培養とサンプリングもサイトAで実 施したトリータビリティー試験と同様なものであった。

その結果として, 約 4 箇月で添加量 $0.2 \%$ のンプルで 良好な分解解効果が確認された。

\subsection{3 サイトBでの原位置実証試験 \\ (1) 浄化促進剂の投入条件}

サイトBでの浄化促進剤の投入条件を表 6 に示す。

浄化促進剤はトリータビリティー分解試験で性能確認 をした大豆油を主成分としたものを使用した。

施工方式は, サイト A とほぼ同様であったが, 施工性向 上のために, 全スリット切削をすべて完了した後に水素徐 放剤を注入する方式に変更した。このことから, 各々の工 程におけるウォータージェットの到達域を確認した。

この確認は, 地盤切削水として加熱水 $\left(\right.$ 約 $\left.60^{\circ} \mathrm{C}\right)$ を, ま た浄化剂として冷水 (約 $15^{\circ} \mathrm{C}$ ) を用い, 地中に予設置し た熱電対で地中の温度変化を測定することにより実施し た。測定深度は, GL-10.2m, GL-11.1m, GL-11.7m の 3 深 度であり,この測定の一例として, GL-10.2m の結果を, 図 13 に示す。現場作業条件の関係から, 注入実施がスリット 切削から 1 時間半近く経過した後となったものの, 計画ど おり半径 $1.25 \mathrm{~m}$ の位置で温度の上昇と下降が検知され, 水 素徐放剂の計画範囲への注入が確認できた。

なお，スリット造成にあたっては，ウォータージェット にエアーを添わせる噴射方式が地盤切削効率を向上 ${ }^{14)}$ せるため,この方式を採用した。

\section{(2) 浄化効果の確認方法}

試験体の配置は, 図 14 に示すとおりであり, 浄化体 (A, B，C）として実施した。土壤モニタリングの位置も同図に 併せて示した。また, 先に述べた熱電対の設置位置もここ に示した。浄化効果の確認は, 土壌を採取・分析して行い, これの採取深度は, GL-9.0m - 12.0m とし, 1 本の調査ボー リングでの分析は GL-9.0, -10.0, - 11.0, $-12.0 \mathrm{~m} の 4$ 深度 のサンプルと, 深度 $25 \mathrm{~cm}$ 毎に均等に混練した 12 サンプ ルで実施し, 合計 16 サンプルとした。分析項目は污染原 因物質である TCE と分解生成物である cis-1,2-DCE および VCとした。

\section{(3) 浄化効果}

土壌を採取して事前と事後の濃度変化を確認した。 施工後, 直ちに実施した結果と 8.5 カ月後に実施した土 壌モニタリング結果を表 7 に示した。なお, 黄色着色部は 土壤溶出量基準值を超過しているが第二溶出量值を超過 していない部位を, また, 茶色着色部は第二溶出量値を超 過している部位を示す。 
表 5 サイト B の污染状況（単位 : $\mathrm{mg} / \mathrm{L}$ ）

\begin{tabular}{|c|c|c|c|c|}
\hline \multirow{2}{*}{$\begin{array}{l}\text { 深度 } \\
\text { (GL) }\end{array}$} & \multicolumn{3}{|c|}{ 対象物質 } & \multirow{2}{*}{$\begin{array}{l}\text { 土 } \\
\text { 層 }\end{array}$} \\
\hline & TCE & $\begin{array}{c}c i s-1, \quad 2 \\
-\mathrm{DCE}\end{array}$ & $\mathrm{VC}$ & \\
\hline$-1.0 \mathrm{~m}$ & 0.034 & 0.003 & $\mathrm{ND}$ & \multirow{8}{*}{ 透水 } \\
\hline$-2.0 \mathrm{~m}$ & ND & $\mathrm{ND}$ & $\mathrm{ND}$ & \\
\hline$-3.0 \mathrm{~m}$ & ND & ND & ND & \\
\hline$-4 . .0 \mathrm{~m}$ & ND & ND & $\mathrm{ND}$ & \\
\hline$-5.0 \mathrm{~m}$ & ND & ND & ND & \\
\hline$-6.0 \mathrm{~m}$ & ND & 0.016 & $\mathrm{ND}$ & \\
\hline$-7.0 \mathrm{~m}$ & ND & 0.030 & $\mathrm{ND}$ & \\
\hline$-8.0 \mathrm{~m}$ & ND & 0.008 & $\mathrm{ND}$ & \\
\hline$-9.0 \mathrm{~m}$ & ND & $\mathrm{ND}$ & $\mathrm{ND}$ & 透 \\
\hline$-9.5 \mathrm{~m}$ & ND & 0.14 & 0.002 & 水 \\
\hline$-10.0 \mathrm{~m}$ & ND & 0.12 & 0.003 & 層 \\
\hline$-10.5 \mathrm{~m}$ & ND & 0.31 & 0.003 & と \\
\hline$-11.0 \mathrm{~m}$ & ND & 0.045 & 0.006 & 難 \\
\hline$-11.5 \mathrm{~m}$ & ND & $\mathrm{ND}$ & $\mathrm{ND}$ & 透 \\
\hline$-12.0 \mathrm{~m}$ & ND & ND & $\mathrm{ND}$ & 水 \\
\hline$-12.5 \mathrm{~m}$ & ND & ND & ND & 層 \\
\hline$-13.0 \mathrm{~m}$ & ND & 0.003 & ND & の \\
\hline$-13.5 m$ & ND & $\mathrm{ND}$ & $\mathrm{ND}$ & 互 \\
\hline$-14.0 \mathrm{~m}$ & ND & ND & $\mathrm{ND}$ & 層 \\
\hline $\begin{array}{l}\text { 溶出 } \\
\text { 基隻 }\end{array}$ & 0.03 & 0.04 & 0.002 & \\
\hline
\end{tabular}

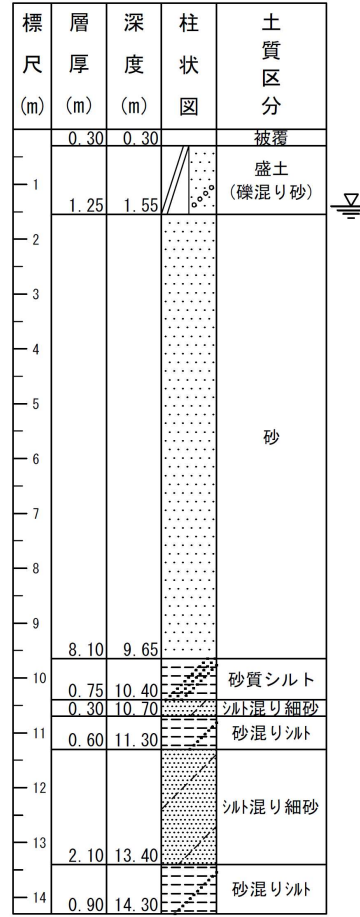

図 12 サイトBの土質柱状図

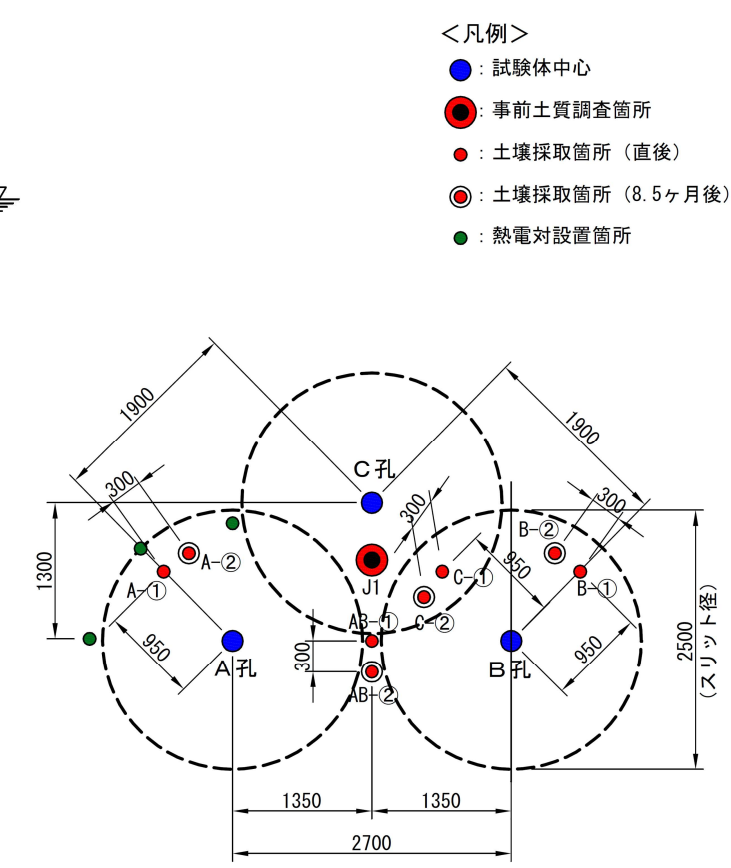

図 14 サイトBにおける浄化効果確認のための ボーリング孔配置図

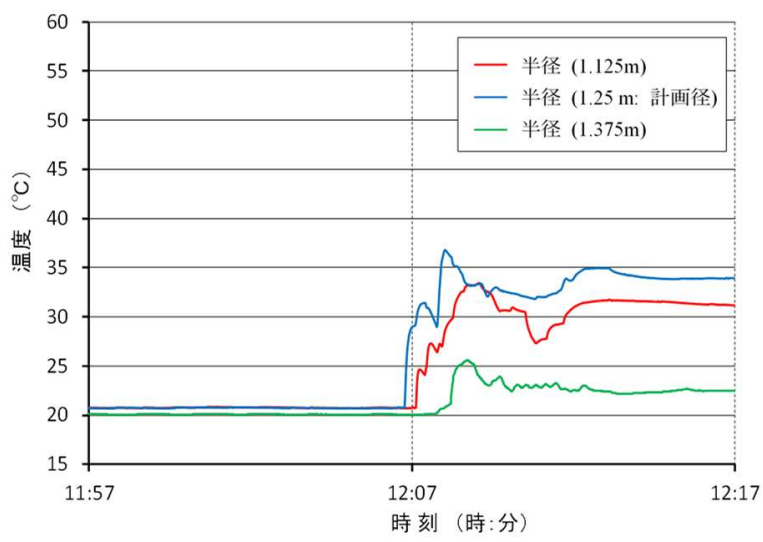

(a) 切削水噴射時 (GL-10.2m)

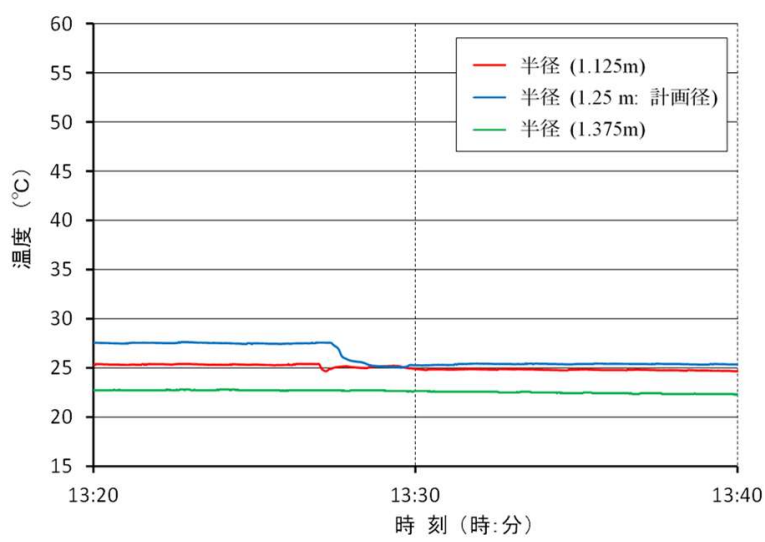

(b) 浄化剂注入時 (GL-10.2m)

図 13 熱電対による温度変化測定結果
表 6 サイトBにおける浄化促進剂の投入条件

\begin{tabular}{|c|c|c|}
\hline \multirow{2}{*}{$\begin{array}{c}\text { 噴射量 } \\
\text { (圧力 }: 40 \mathrm{MPa} \text { ) }\end{array}$} & 清水（地盤切削） & $70 \mathrm{~L} / \mathrm{min}$ \\
\hline & 浄化剤（注入） & $70 \mathrm{~L} / \mathrm{min}$ \\
\hline \multirow{2}{*}{ 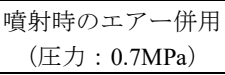 } & 清水（地盤切削） & あり $\left(3 \mathrm{~N} \mathrm{~m}^{3} / \mathrm{min}\right)$ \\
\hline & 浄化剂（注入） & なし \\
\hline \multicolumn{2}{|c|}{ 対象範囲 } & $\varphi 2.5 \mathrm{~m}$ \\
\hline \multicolumn{2}{|c|}{ 対象深度 $(\mathrm{H}=3.0 \mathrm{~m})$} & GL-9.0m $\sim 12.0 \mathrm{~m}$ \\
\hline \multicolumn{2}{|c|}{ 注入ゾーン土量 } & $14.7 \mathrm{~m}^{3} /$ 本 \\
\hline \multicolumn{2}{|c|}{ スリット数 } & 11 スリット \\
\hline \multicolumn{2}{|c|}{ スリット間隔 } & $0.3 \mathrm{~m}$ \\
\hline
\end{tabular}

また，一例としてこの表の中から A-(1)と A-(2)の結果を グラフ化して図 15 に示した。なお, TCE は施工前後です べて検出限界值未満であったことから記載を省略した。8 カ半月後のモニタリング結果として VCを含めてほぼす心゙ てで環境基準值までの浄化が確認された。

\section{3 .4 実証サイトBについての考察}

実験サイトは，過去実施された揚水等の対策により帯水 砂層の污染はほぼ浄化されているものの, 難透水層におい ては污染原因物質である TCE の分解生成物である cis-1,2DCE と VC が基準值より 1 オーダーのレベルで超過して 検出されていた。今回，この難透水層中に水素徐放剤をウ オータージェット技術でスリット状に注入する方式での 実験を行い, 注入後 8.5 ケ月経過した時点でモニタリング した結果，ほぼ完全な VOCs の分解を確認した。

本浄化手法は従来の混合擋挥方式に比べると浄化速度 は遅いものの, 地盤を泥濘化させずにすむ方式であり, 比 較的低濃度の污染の場合であれば, 難透水性地盤であって も 1 年以内で浄化できる可能性を確認できた。 
表 7 サイトBにおける浄化の進捗状況（単位：mg/L)

\begin{tabular}{|c|c|c|c|c|c|c|c|c|c|}
\hline \multirow{2}{*}{\multicolumn{2}{|c|}{$\begin{array}{c}\text { モニタリング } \\
\text { 位置 } \\
\end{array}$}} & \multicolumn{2}{|c|}{$\mathrm{A}$} & \multicolumn{2}{|c|}{$\mathrm{B}$} & \multicolumn{2}{|c|}{$\mathrm{C}$} & \multicolumn{2}{|c|}{$\mathrm{AB}$} \\
\hline & & (1) & (2) & (1) & (2) & (1) & (2) & (1) & (2) \\
\hline \multicolumn{2}{|c|}{ 対象物質 } & \multicolumn{8}{|c|}{$c i s-1,2-\mathrm{DCE}$} \\
\hline \multicolumn{2}{|c|}{ 測定時期 } & $\begin{array}{l}\text { 施工 } \\
\text { 直後 }\end{array}$ & $\begin{array}{c}8.5 \text { ヶ } \\
\text { 月後 }\end{array}$ & $\begin{array}{l}\text { 施工 } \\
\text { 直後 }\end{array}$ & $\begin{array}{c}8.5 \text { ケ } \\
\text { 月後 } \\
\end{array}$ & $\begin{array}{l}\text { 施工 } \\
\text { 直後 }\end{array}$ & $\begin{array}{l}8.5 \text { ケ } \\
\text { 月後 }\end{array}$ & $\begin{array}{l}\text { 施工 } \\
\text { 直後 }\end{array}$ & $\begin{array}{r}8.5 \text { ケ } \\
\text { 月後 }\end{array}$ \\
\hline \multirow{16}{*}{$\begin{array}{l}\text { 深度 } \\
(\mathrm{GL})\end{array}$} & -9.00 & ND & ND & 0.002 & ND & ND & ND & ND & ND \\
\hline & -9.13 & 0.008 & ND & 0.015 & ND & ND & ND & 0.002 & ND \\
\hline & -9.38 & 0.006 & ND & 0.012 & ND & ND & ND & 0.002 & ND \\
\hline & -9.63 & ND & ND & ND & ND & ND & ND & ND & ND \\
\hline & -9.88 & ND & 0.012 & 0.007 & ND & ND & ND & ND & ND \\
\hline & -10.00 & ND & 0.006 & ND & ND & ND & ND & ND & ND \\
\hline & -10.13 & 0.005 & 0.003 & 0.004 & ND & 0.50 & ND & 0.18 & 0.009 \\
\hline & -10.38 & 0.013 & ND & ND & ND & 0.47 & ND & 0.18 & 0.004 \\
\hline & -10.63 & 0.10 & ND & 0.011 & ND & 0.79 & ND & 0.29 & ND \\
\hline & -10.88 & 0.14 & ND & 0.051 & ND & 0.13 & ND & 0.067 & ND \\
\hline & -11.00 & 0.26 & ND & 0.072 & ND & 0.085 & ND & 0.030 & ND \\
\hline & -11.13 & 0.11 & ND & 0.014 & ND & 0.079 & ND & ND & ND \\
\hline & -11.38 & 0.020 & ND & ND & ND & 0.054 & ND & ND & ND \\
\hline & -11.63 & ND & ND & ND & ND & 0.004 & ND & 0.003 & ND \\
\hline & -11.88 & ND & ND & 0.034 & ND & 0.018 & ND & 0.012 & ND \\
\hline & -12.00 & ND & ND & 0.064 & ND & 0.038 & ND & 0.006 & ND \\
\hline \multicolumn{2}{|c|}{ 溶出基準 } & \multicolumn{8}{|c|}{0.04} \\
\hline \multicolumn{2}{|c|}{ 対象物質 } & \multicolumn{8}{|c|}{$\mathrm{VC}$} \\
\hline \multirow{16}{*}{$\begin{array}{l}\text { 深度 } \\
(\mathrm{GL})\end{array}$} & -9.00 & ND & ND & 0.002 & 0.001 & ND & ND & ND & ND \\
\hline & -9.13 & 0.004 & ND & ND & ND & ND & ND & 0.001 & ND \\
\hline & -9.38 & 0.003 & ND & 0.003 & ND & ND & ND & 0.002 & ND \\
\hline & -9.63 & 0.003 & ND & 0.002 & ND & ND & ND & ND & ND \\
\hline & -9.88 & 0.002 & ND & ND & ND & ND & ND & ND & ND \\
\hline & -10.00 & ND & ND & 0.002 & ND & ND & ND & ND & ND \\
\hline & -10.13 & ND & 0.003 & ND & ND & 0.003 & ND & 0.021 & 0.005 \\
\hline & -10.38 & ND & ND & 0.002 & ND & ND & ND & 0.020 & 0.001 \\
\hline & -10.63 & ND & ND & ND & ND & ND & ND & 0.035 & ND \\
\hline & -10.88 & ND & ND & 0.002 & ND & 0.005 & ND & ND & ND \\
\hline & -11.00 & 0.004 & ND & 0.002 & ND & ND & ND & 0.001 & ND \\
\hline & -11.13 & 0.007 & ND & ND & ND & 0.005 & ND & 0.002 & ND \\
\hline & -11.38 & 0.002 & ND & ND & ND & 0.110 & ND & ND & ND \\
\hline & -11.63 & ND & ND & ND & ND & ND & ND & 0.001 & ND \\
\hline & -11.88 & ND & ND & 0.013 & ND & 0.002 & ND & 0.001 & ND \\
\hline & -12.00 & ND & ND & 0.026 & ND & 0.007 & ND & 0.001 & ND \\
\hline \multicolumn{2}{|c|}{ 溶出基準 } & \multicolumn{8}{|c|}{0.002} \\
\hline
\end{tabular}

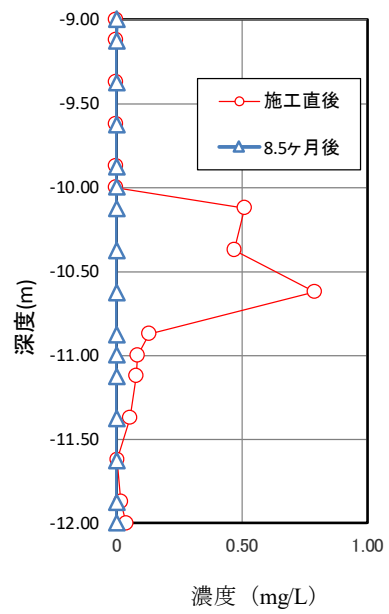

(1) $c i s-1,2-\mathrm{DCE}$

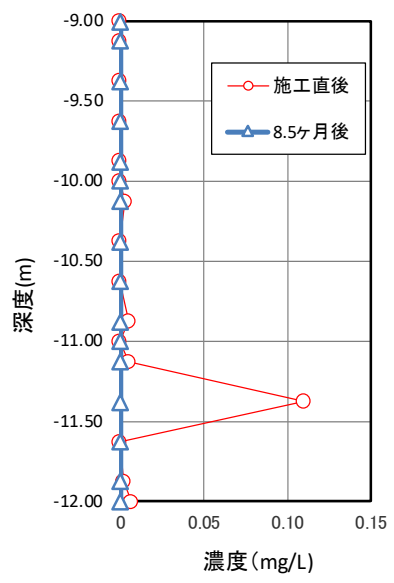

(2) $\mathrm{VC}$

図 15 サイト Bにおける浄化の進捗状況 (モニタリング位置 : C-(1)，(2)
任意の深度のみに施工できる技術であることから，透水層 と難透水層の層境部を対象とした浄化も可能であり，揚水 浄化等に伴う地下水への污染の再溶出対策としての活用 も期待できる。

\section{4. 結論と今後の課題}

難透水性地層におけるクロロエチレン類のバイオレメ ディエーションを実現させるために, 本研究では, 水素分 子の拡散に注目し，ウォータージェットで掘削したスリッ 卜面を利用した平面的拡散に基づく原位置浄化技術を考 案し，実污染サイトでの検証試験を実施した。

二つの実污染サイトにおいて, 難透水性地層にウォータ ージェットで掘削したスリット面を利用し，水素徐放剤を $0.3 \mathrm{~m}$ の間隔で薄く多層に投入し, 水素分子の拡散によるク ロロエチレン類の微生物分解の促進が確認された。PEC の 初期污染濃度 $75 \mathrm{mg} / \mathrm{L}$ である高濃度污染 (実污染サイトA)
条件下では，水素徐放剤を投入した後 25 ケ月で PCE がほ ぼ分解された。また, cis-1,2-DCE の最大残留初期濃度 0.79 $\mathrm{mg} / \mathrm{L}$ の条件下(実污染サイト B)では，水素徐放剤を投入し た後 8.5 力月でほぼ完全な cis-1,2-DCE と VC の分解が確 認された。これら現場実証試験の結果より，ウォータージ エットによる埩化促進剤の投入と平面的拡散を併用した 技術の有効性を実証した。

なお，今後の課題として埩化期間予測のほか，トリータ ビリティー試験や室内でのモデル実験からの推定, また実 装して実污染サイト浄化に関する実測データと実績を蓄 積することにより開発技術の適用範囲, 適用条件及び適用 限界などを明らかにすることが必要であると考えている。

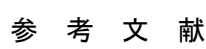

1) 環境省 水 $\cdot$ 大気環境局 : 平成26年度土壌污染対策法の施行状 沉及び土壌污染調査・対策事例等に関する調查結果, p.37, 2016 
2）竹内美緒：地下圈微生物活動に対する難透水層の役割，地 学雑誌, 116 (6) pp.916-917, 2017.

3) Chambon, C. J., Broholm, M. M., Binning J. P. and Bjerg L. P.: Modeling Multi-Component Transport and Enhanced Anaerobic Dechlorination Processes in A Single Fracture-Clay Matrix System, Journal of Contaminant Hydrology 112, pp. 77-90, 2009.

4) 川端淳一, 河合達司, 伊藤圭二郎，上澤進 : ウォータージ エットを用いた污染地盤の修復技術について，土と基礎・ 地盤工学会誌, Vol.50, No.10, pp.25-27, 2002.

5) 塩尻大輔, 北詰昌義, 佐久間孝夫, 熊沢章, 和知剛, 小松 大祐 : 高圧噴射擋拌工法の原位置バイオレメディエーショ ンへの適用事例（その 2 ），第 21 回地下水・土壌污染とそ の防止対策に関する研究集会 (CD-ROM) S1-17, pp. 71-74, 2015.

6) Scheutz C., Broholm M M., Durant D.N., Weeth E. B., Jørgensen T. H., Dennis P., Jacobsen S.C., Cox E.E., Chambon C. J. and Bjerg L.P.: Field Evaluation of Biological Enhanced Reductive Dechlorination of Chloroethenes in Clayey Till, Environ. Sci. Technol., 44 (13), pp. 5134-5141, 2010.

7) Takeuchi, M., Kawabe, Y., Watanabe, E., Oiwa, T., Takahashi, M., Nanba, K., Kamagata, Y., Hanada, S., Ohko, Y. and Komai, T.: Comparative Study of Microbial Dechlorination of Chlorinated Ethenes in An Aquifer and A Clayey Aquitard, J Contam Hydrol, Vol. 124, pp. 14-24, 2011.
8) Yoshikawa, M., Takeuchi, M. and Zhang, M.: Distribution of Dehalococcoides 16S rRNA and Dehalogenase Genes in Contaminated Sites, Environment and Natural Resources Research, Vol. 7, No. 2, pp. 37-46, 2017.

9）吉川美穂，上沢進，和田忠輔，張銘，竹内美緒，駒井武 : VOCs 污染と浄化対策技術 その 3 : 溶存水素拡散試験技 術の開発，第 16 回地下水・土壌污染とその防止対策に関 する研究集会 (CD-ROM) S6-25,pp.677-682, 2010.

10) Yoshikawa, M., Zhang, M., Takeuchi, M. and Komai, T.: Diffusion Study on Dissolved Hydrogen toward Effective Bioremediation of Chlorinated Ethenes in Aquitards, AGU Fall Meeting, San Francisco, USA, 2010.

11）上沢進，張銘，駒井武：難透水性地盤におけるバイオレメ ディエーションのための浄化促進剤投入方式に関する研 究，地盤工学ジャーナル（採択）

12) U.S. Environmental Protection Agency: Hydraulic Fracturing Technology, EPA/540/SR-93/505, 6p, 1993.

13）中間哲志，大澤武彦，山内仁，安原雅子，西村実：ハイド ロフラクチャー法を応用した VOCs 污染土壤の原位置浄化 方法, 土木学会第 59 回年次学術講演会 第 7 部門, pp.509510, 2004.

14）八尋睴夫, 吉田宏, 西謙治 : わかりや寸い建築技術ウォー タージェットを利用した地下工法, 鹿島出版会, 1983, pp.4-20.

（2018.10.16 受付） 


\title{
IN SITU DEMONSTRATION OF THE APPROACHES FOR INJECTING BIOREMEDIATION ENHANCEMENT AGENT INTO LOW-PERMEABLE GEOFORMATIONS USING WATERJET
}

\author{
Susumu UESAWA ${ }^{1}$, Ming ZHANG ${ }^{2}$, Robert C. BORDEN ${ }^{3}$ and Takeshi KOMAI ${ }^{4}$ \\ 1 Head Office, Chemical Grouting Co. Ltd. \\ 2 Geological Survey of Japan, Institute for Geo-Resources and Environment, National Institute of \\ Advanced Industrial Science and Technology \\ 3 EOS Remediation, LLC \\ 4 Graduate School of Environmental Studies, Tohoku University
}

\begin{abstract}
Injection of hydrogen release compound can enhance bioremediation process of chloroethylenes in situ. In the case of remediating low-permeable formations, difficulties can be induced due to hard permeation of enhancement agent for injection method or dissolution of formation into mud for stirring method. To overcome these difficulties, we proposed an approach that injects hydrogen release compound into slits cut by waterjet with a curtain interval considering the advantage of using planar diffusion based on the theoretical examination. In situ demonstration tests were performed at two contaminated sites with a slit interval of $0.3 \mathrm{~m}$. The results demonstrated that for low concentration contamination, the site could be almost completely remediated within 8.5 months, and for high concentration contamination with the maximum PCE concentration of $75 \mathrm{mg} / \mathrm{L}$, it could be degraded to below the environmental standard $(0.01 \mathrm{mg} / \mathrm{L})$ within 2 years. The effectiveness of using waterjet for injecting bioremediation enhancement agent based on planar diffusion was verified through the in situ demonstration tests.
\end{abstract}

Key words: bioremediation, chloroethylenes, low-permeable formation, hydrogen release compound, waterjet 